\title{
Viscosity of the $\mathrm{CaO}_{-} \mathrm{CaF}_{2}$ System Containing Chromium Oxide
}

\author{
O. I. OSTROVSKI, YU. I. UTOCHKIN, ${ }^{1)}$ A. V. PAVLOV ') and R. A. AKBERDIN ${ }^{11}$
}

School of Materials Science and Engineering, University of New South Wales, PO Box 1, Kensington, NSW 2033, Australia. 1) Department of Electrometallurgy of Steel \& Ferroalloys, Moscow Steel and Alloys Institute, Russia, Moscow, Leninskiy Prospect, 4.

(Received on May 20, 1994; accepted in final form on June 24, 1994)

\begin{abstract}
Viscosity of the $\mathrm{CaO}-\mathrm{CaF}_{2}-\mathrm{Cr}_{2} \mathrm{O}_{3}$ system $\left(15 \%<\mathrm{CaO}<25 \%, 75 \%<\mathrm{CaF}_{2}<85 \%, 0 \%<\mathrm{Cr}_{2} \mathrm{O}_{3}<10 \%\right)$ was measured by the vibrational resonant amplitude method. From the experimental data on slags viscosity as a function of temperature, liquidus temperatures were determined. Viscosities and liquidus temperatures were found to increase with an increase in the chromium oxide concentration in the slag.
\end{abstract}

KEY WORDS: viscosity; slag; chromium oxide; liquidus temperature.

\section{Introduction}

The data on the viscosity and liquidus temperature of slags containing chromium oxides are of importance for the refining of steels containing chromium in the dephosphorization and desulfurization processes. Requirements for fluxes and slags used in the refining processes include high phosphate and sulfide capacities and low viscosity. These requirements are met by the $\mathrm{CaO}$-based fluxes including $\mathrm{CaO}-\mathrm{CaF}_{2}$ flux which are widely used in the steelmaking practice. However, during treatment of steel containing chromium even under low oxidizing conditions, chromium inevitably oxidizes and transfers to the slag phase affecting slags properties. Thus, even small addition of chromium oxide to the binary $\mathrm{CaO}-\mathrm{CaF}_{2}$ significantly decreases its phosphate capacity. ${ }^{1)}$ Chromium oxide has a similar effect on the sulfide capacity of the CaO-based slags. ${ }^{2)}$ In this study the effect of chromium oxide on the viscosity of the $\mathrm{CaO}-\mathrm{CaF}_{2}$ system and liquidus temperature is investigated.

\section{Experimental}

\subsection{Viscosity and Liquidus Temperature of the $\mathrm{CaO}$ - $\mathrm{CaF}_{2}-\mathrm{Cr}_{2} \mathrm{O}_{3}$ System}

Viscosities of $\mathrm{CaO}-\mathrm{CaF}_{2}-\mathrm{Cr}_{2} \mathrm{O}_{3}$ slags were measured by the vibrational resonant amplitude method. This method is based on the fact that the amplitude of forced oscillations of a spindle immersed into the liquid is related to the viscosity of the liquid. The construction of the vibrational viscometer used was described by Arsentiev et $a .^{3)}$ Samples for the experiments were prepared from $\mathrm{CaO}, \mathrm{CaF}_{2}$ and $\mathrm{Cr}_{2} \mathrm{O}_{3}$, calcined at $1050^{\circ} \mathrm{C}$ in air for $3.5 \mathrm{hr}$. Three master slags $\mathrm{CaO}(15 \mathrm{wt} \%)-\mathrm{CaF}_{2}(85$ wt $\%), \mathrm{CaO}(25 \mathrm{wt} \%)-\mathrm{CaF}_{2}(75 w \mathrm{t} \%)$ and $\mathrm{CaO}(18 \mathrm{wt} \%)$ $\mathrm{CaF}_{2}(72 \mathrm{wt} \%)-\mathrm{Cr}_{2} \mathrm{O}_{3}(10 \mathrm{wt} \%)$ were smelted in the graphite (first two slags) or molybdenum (third one) crucibles. Other samples, whose chemical compositions are given in Table 1, were melted from these master slags in the viscometer Tamman-type furnace with a graphite heater. The compositions of samples were chosen to cover the following field of compositions of the $\mathrm{CaO}-\mathrm{CaF}_{2}$ $\mathrm{Cr}_{2} \mathrm{O}_{3}$ system (wt\%): $15 \%<\mathrm{CaO}<25 \%, \quad 75 \%<$ $\mathrm{CaF}_{2}<85 \%, 0 \%<\mathrm{Cr}_{2} \mathrm{O}_{3}<10 \%$.

Measurements were carried out under an argon atmosphere in the molybdenum crucible of $20 \mathrm{~mm}$ internal diameter and $35 \mathrm{~mm}$ height. The sample mass was approximately $30 \mathrm{~g}$. A spindle was made from the molybdenum rod $(300 \mathrm{~mm}$ length and $1.5 \mathrm{~mm}$ diameter). The depth of immersion was $10 \mathrm{~mm}$. The temperature was measured using a tungsten-rhenium thermocouple and was varied from $1700^{\circ} \mathrm{C}$ down to $1300^{\circ} \mathrm{C}$ with rate $1-3^{\circ} \mathrm{C} / \mathrm{min}$. The viscometer was calibrated using liquids with known viscosity.

From the experimental data on slags viscosity as a function of temperature, liquidus temperatures were determined. For this, the viscosity function of temperature was expressed as

$$
\mu=A \exp \left(\frac{E}{T}\right)
$$

where $A$ and $E$ are constants. The liquidus temperature was indicated by the sharp change in the slope of the $\log \mu$ vs. $1 / T$.

Table 1. Chemical composition (wt $\%$ ) of samples for viscosity measurements.

\begin{tabular}{lcccccccccc}
\hline No. & 1 & 2 & 3 & 4 & 5 & 6 & 7 & 8 & 9 & 10 \\
\hline $\mathrm{CaO}$ & 15 & 25 & 18 & 18.3 & 16 & 21.7 & 17 & 22.7 & 20.3 & 19.5 \\
$\mathrm{CaF}$ & 85 & 75 & 72 & 81.7 & 80.7 & 78.3 & 76.3 & 74 & 73 & 77.3 \\
$\mathrm{Cr}_{2} \mathrm{O}_{3}$ & - & - & 10 & - & 9.3 & - & 6.7 & 3.3 & 6.7 & 3.3 \\
\hline
\end{tabular}




\section{Results and Discussion}

The slag viscosity measured as a function of temperature is illustrated in Fig. 1. Liquidus temperature was determined from plots of $\log \mu$ against the reciprocal temperature, as shown in Fig. 2. Liquidus temperature and viscosity of the $\mathrm{CaO}-\mathrm{CaF}_{2}-\mathrm{Cr}_{2} \mathrm{O}_{3}$ system $(\mathrm{CaO} /$ $\left.\mathrm{CaF}_{2}=1 / 4\right)$ as functions of $\mathrm{Cr}_{2} \mathrm{O}_{3}$ concentration are

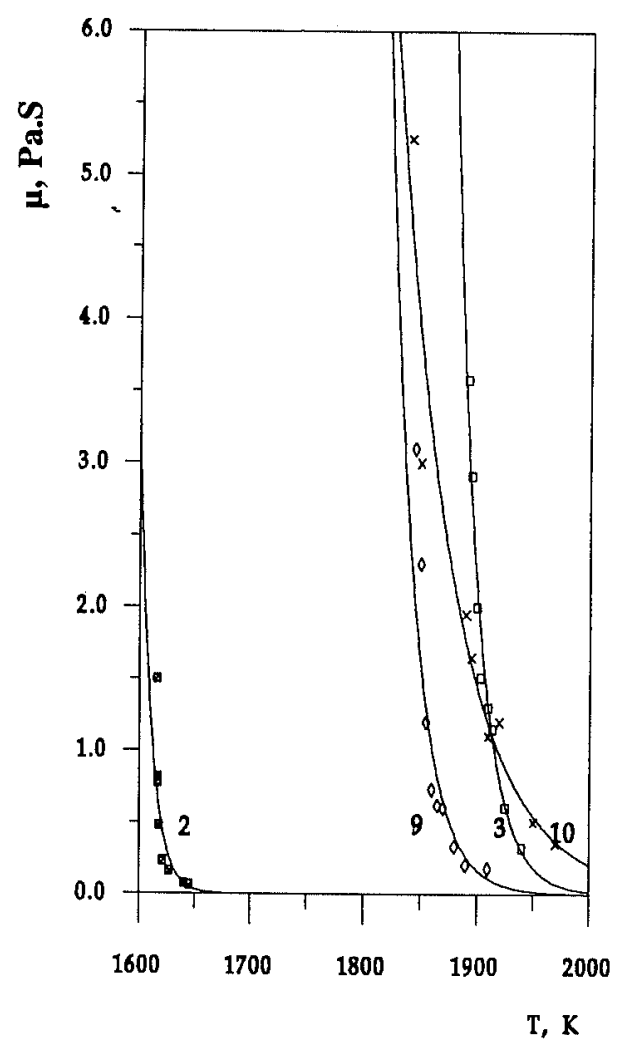

Fig. 1. Variation of slag viscosity with temperature. For slag composition see Table 1.

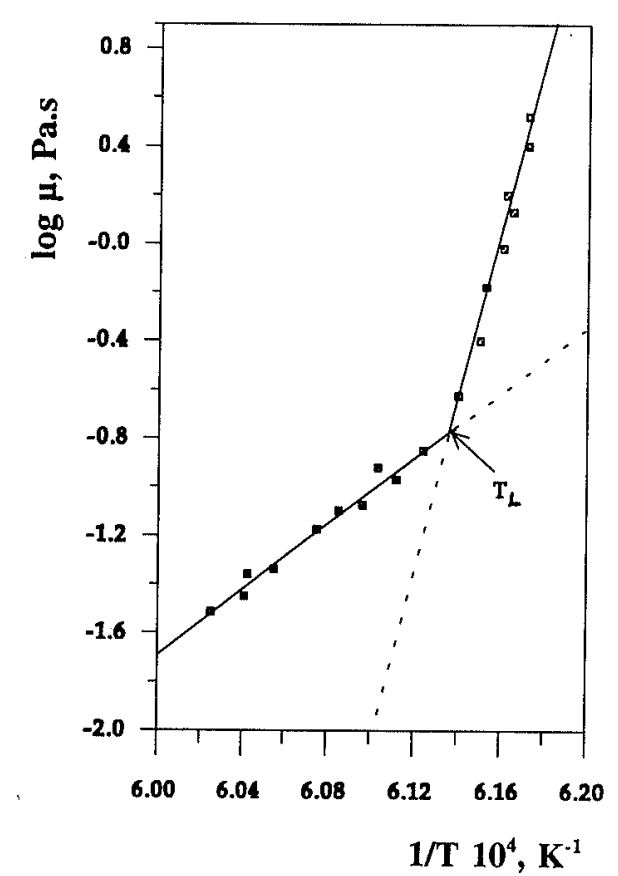

Fig. 2. Illustration of the technique used to determine the liquidus temperature $\left(T_{L}\right)$ for $\mathrm{CaO}-\mathrm{CaF}_{2}$ slag (18.3 wt \% $\mathrm{CaO}, 81.7 \mathrm{wt} \% \mathrm{CaF}_{2}$ ) using the logarithm of viscosity plotted against reciprocal temperature. presented in Fig. 3. The addition of chromium oxides to the $\mathrm{CaO}-\mathrm{CaF}_{2}$ system results in the increasing liquidus temperature and viscosity of this system.

Data on the viscosity of the ternary $\mathrm{CaO}-\mathrm{CaF}_{2}-\mathrm{Cr}_{2} \mathrm{O}_{3}$ system were not found in literature. Increase in viscosity with increasing $\mathrm{Cr}_{2} \mathrm{O}_{3}$ concentration was reported for $\mathrm{CaO}-\mathrm{CaF}_{2}-\mathrm{Cr}_{2} \mathrm{O}_{3}-\mathrm{Al}_{2} \mathrm{O}_{3}$ system ${ }^{4)}$ and for $\mathrm{CaO}-\mathrm{SiO}_{2}-$ $\mathrm{MgO}-\mathrm{Cr}_{2} \mathrm{O}_{3}$ system. ${ }^{5)}$

Mohanty and $\mathrm{Kay}^{6}$ ) studied the activity of chromium oxide in the $\mathrm{CaO}-\mathrm{CaF}_{2}-\mathrm{Cr}_{2} \mathrm{O}_{3}$ system. It follows from their data that liquid phase extends to a much higher $\mathrm{Cr}_{2} \mathrm{O}_{3}$ concentration (to about $12 \%$ at $1500^{\circ} \mathrm{C}$, Fig. 4) than was found in this work. Kanzaki et al. ${ }^{7)}$ studied the solubility of $\mathrm{CaO} \cdot \mathrm{Cr}_{2} \mathrm{O}_{3}$ in the $\mathrm{CaO}-\mathrm{CaF}_{2}$ system at $1500^{\circ} \mathrm{C} . \mathrm{Cr}_{2} \mathrm{O}_{3}$ content in the $\mathrm{CaO} \cdot \mathrm{Cr}_{2} \mathrm{O}_{3}$-saturated slags varied from 0.80 to $1.28 \mathrm{wt} \%$ with increasing $\mathrm{CaO}$ content from 15.6 to $20.6 \%$. This is close to the data obtained in the present work. It is seen from Fig. 4, where data on $\mathrm{Cr}_{2} \mathrm{O}_{3}$ solubility in the $\mathrm{CaO}-\mathrm{CaF}_{2}-\mathrm{Cr}_{2} \mathrm{O}_{3}$ system are plotted against $\mathrm{CaO}$ content at 1500,1550 and $1600^{\circ} \mathrm{C}$.
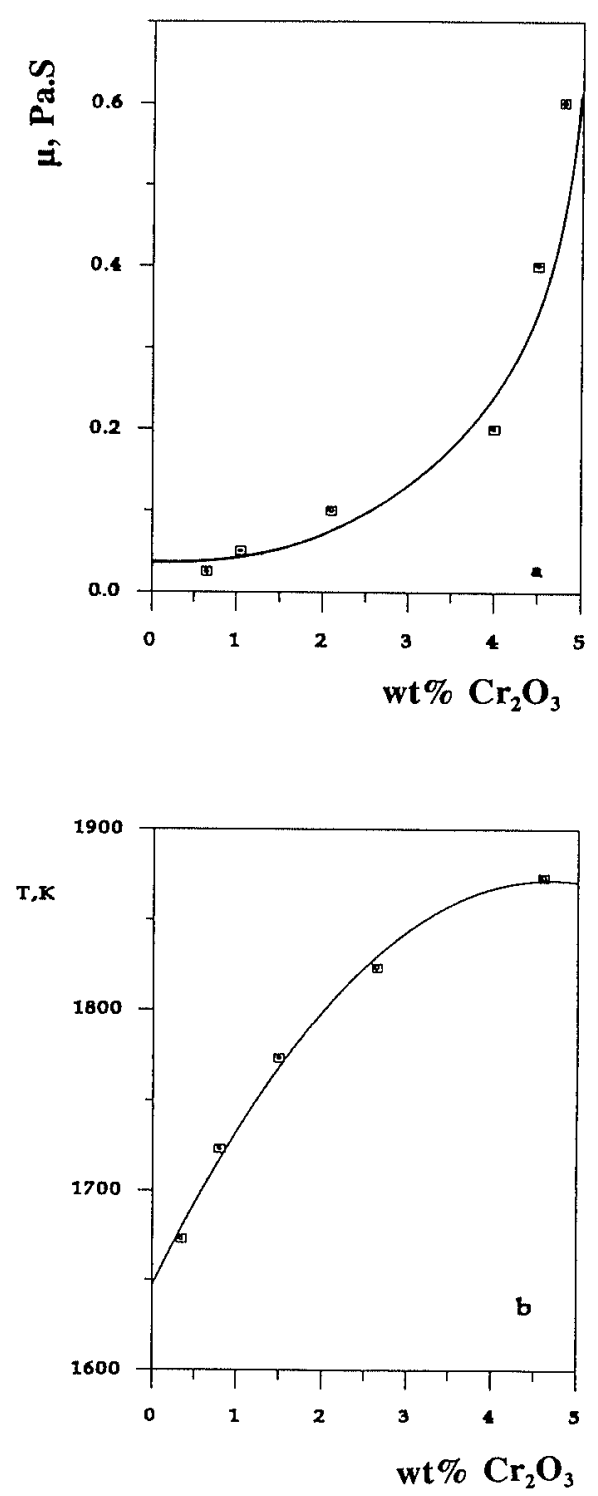

Fig. 3. Variation of (a) slag viscosity at $1600^{\circ} \mathrm{C}$ and (b) liquidus temperature with $\mathrm{Cr}_{2} \mathrm{O}_{3}$ concentration for $(\% \mathrm{CaO}) /\left(\% \mathrm{CaF}_{2}\right)=1 / 4$. 
ISIJ International, Vol. 34 (1994), No. 9

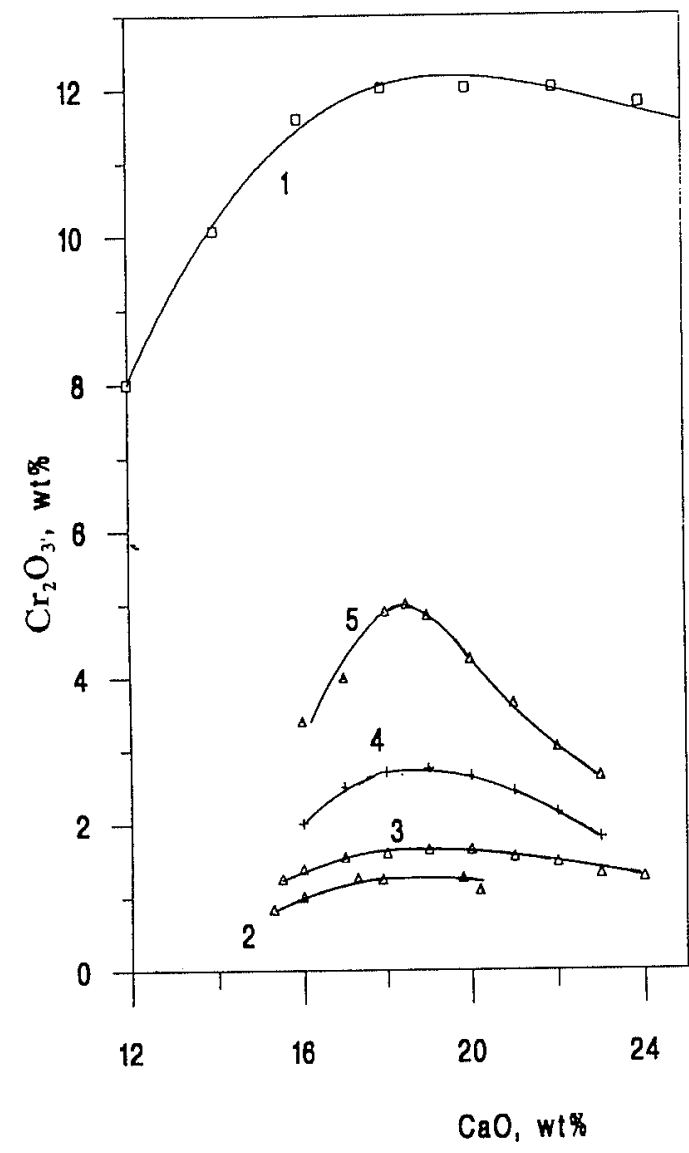

\section{Conclusion}

Measurements of viscosity of $\mathrm{CaO}(15-25 \%)-\mathrm{CaF}_{2}(75-$ $85 \%)-\mathrm{Cr}_{2} \mathrm{O}_{3}(0-10 \%)$ slags showed that $\mathrm{Cr}_{2} \mathrm{O}_{3}$ oxide increases the slag viscosity and liquidus temperature.

\section{REFERENCES}

1) O. I. Ostrovski, Yu. I. Utochkin, A. V. Pavlov and R. Akberdin: ISIJ Int., 34 (1994), No. 10.

2) E. Drakaliysky, N. S. Srinivasan and L.-I. Staffansson: Scand. J. Metall., 20 (1991), 251.
Fig. 4.

Solubility of chromium oxide in the $\mathrm{CaO}-\mathrm{CaF}_{2}-\mathrm{Cr}_{2} \mathrm{O}_{3}$ system as a function of $\mathrm{CaO}$ concentration at $1500^{\circ} \mathrm{C}$ (curves 1,2 and 3 ), $1550^{\circ} \mathrm{C}$ (curve 4) and $1600^{\circ} \mathrm{C}$ (curve 5). Curve 1 was drawn using data ${ }^{6}$; curve 2 was taken from Ref. 7); curves 3, 4 and 5: present study.

3) P. P. Arsentiev, V. V. Yakovlev, M. G. Krasheninnikov, L. A. Pronin and E. S. Filippov: Physicochemical Methods of Investigation of Metallurgical Processes, Metallurgiya, Moscow, (1988) (in Russian).

4) G. I. Zhmoidin: Viscosity of $\mathrm{CaO}-\mathrm{Al}_{2} \mathrm{O}_{3}-\mathrm{CaF}_{2}$ System, VINITI, Moscow, (1988) (in Russian).

5) E. Minami, M. Amatatsu and N. Sano: Tetsu-to-Hagané, 73 (1987), $\mathbf{S 8 7 1 .}$

6) A. K. Mohanty and A. R. Kay: Metall Trans. B., 6B (1975), 159.

7) Y. Kanzaki, F. Tsukihashi and N. Sano: Tetsu-to-Hagané, 80 (1994), 13. 